\title{
Predicting the Diversity of Foreign Entry Modes
}

\author{
Hashai, Niron; Geisler Asmussen, Christian; Benito, Gabriel; Petersen, Bent
}

Document Version

Final published version

Publication date:

2007

License

CC BY-NC-ND

Citation for published version (APA):

Hashai, N., Geisler Asmussen, C., Benito, G., \& Petersen, B. (2007). Predicting the Diversity of Foreign Entry Modes. Center for Strategic Management and Globalization. SMG Working Paper No. 3/2007

Link to publication in CBS Research Portal

\section{General rights}

Copyright and moral rights for the publications made accessible in the public portal are retained by the authors and/or other copyright owners and it is a condition of accessing publications that users recognise and abide by the legal requirements associated with these rights.

\section{Take down policy}

If you believe that this document breaches copyright please contact us (research.lib@cbs.dk) providing details, and we will remove access to the work immediately and investigate your claim. 
Predicting the Diversity of Foreign Entry Modes

\author{
Niron Hashai \\ Christian G. Asmussen \\ Gabriel R.G. Benito \\ Bent Petersen
}

SMG WP 3/2007

March 2007 
SMG Working Paper No. 3/2007

March 2007

ISBN: 978-87-91815-02-7

Center for Strategic Management and Globalization Copenhagen Business School

Porcelænshaven 24

2000 Frederiksberg

Denmark

www.cbs.dk/smg 


\title{
Predicting the Diversity of Foreign Entry Modes
}

\author{
Niron Hashai* \\ Jerusalem School of Business Administration \\ The Hebrew University \\ Mount Scopus \\ Jerusalem 91905 \\ Israel \\ Tel: $+972-(0) 2-5883110$ \\ Fax: +972-(0)2-5881341 \\ E-mail: nironH@huji.ac.il
}

Christian G. Asmussen

Center for Strategic Management and Globalization

Copenhagen Business School

Denmark

Gabriel R.G. Benito

Department of Strategy and Logistics,

BI Norwegian School of Management, Oslo

Norway

\section{Bent Petersen}

Center for Strategic Management and Globalization

Copenhagen Business School

Denmark

* Corresponding author.

We wish to thank Ulf Anderson and Ram Mudambi for their useful comments and Tamar Almor and Seev Hirsch for allowing us to use their dataset. Niron Hashai acknowledges the financial support of the Asper Center for Entrepreneurship at the Hebrew University. 


\title{
Predicting the Diversity of Foreign Entry Modes
}

\begin{abstract}
This paper expands entry mode literature by referring to multiple modes exerted in different value chain activities within and across host markets, rather than to a single entry mode at the host market level. Scale of operations and knowledge intensity are argued to affect firms' entry mode diversity across value chain activities and host markets. Analyzing a sample of Israeli based firms we show that larger firms exhibit a higher degree of entry mode diversity both across value chain activities and across host markets. Higher levels of knowledge intensity are also associated with more diversity in firms' entry modes across both dimensions.
\end{abstract}

Key Words: entry mode, diversity, value chain activities, firm size, knowledge intesity. 


\section{Predicting the Diversity of Foreign Entry Modes}

\section{Introduction}

Firms' foreign market entry mode choice is one of the most researched topics in international business (e.g. Anand \& Delios, 1997; Datta, Herrmann \& Rasheed, 2002; Delios \& Henisz, 2003; Malhotra, Agarwal \& Ulgado., 2003; Madhok, 1997; Martin \& Salomon, 2003; Melin, 1992; Pedersen et al., 2002) ${ }^{1}$. Yet, despite the considerable attention devoted to this topic, the conceptualization of "entry modes" remains, by and large, a single dimensional construct referring to a specific mode exerted by a firm in a given foreign market - be it exports, licensing, joint ventures, wholly owned greenfield or acquired subsidiaries and so forth. This highly simplified view of entry modes, while convenient and useful for theory building, stands in stark contrast to the complexity of entry modes that can be observed in real-world firms. For instance, let us examine the entry modes of Gilat Satellite Networks as they appeared in 1999. Gilat is an Israeli based provider of end-to-end telecommunications and data networking solutions via satellite. In the United States Gilat's R\&D and production operations were conducted both via greenfield and acquired wholly owned subsidiaries. Distribution and customer support to the American market, on the other hand, were simultaneously provided through local independent distributors, a sales office, a strategic alliance and a joint venture. Interestingly, identical entry modes for $\mathrm{R} \& \mathrm{D}$, production, distribution and customer support were used by Gilat in the European Union. On the other hand, for its operations is South and Central America, Gilat used acquired R\&D operations, acquired production operations in parallel to a

\footnotetext{
${ }^{1}$ While the term "entry mode" seems to refer to the starting of operations in a foreign market, traditionally it is also used when describing the long term operations of a firm in a foreign market, regardless of its timing. In what follows we therefore adopt this notion and use the term "entry mode" to portray the variety of long term foreign operation modes.
} 
joint venture manufacturing facility and provided distribution and customer support through agents, strategic alliances and acquired wholly owned subsidiaries. Finally, in South East Asia Gilat only had joint venture production operations and strategic alliances for distribution and customer support. Hence, considering the global operations of Gilat, we note that the firm had two different entry modes for R\&D, three different entry modes for production, and five different entry modes for distribution and customer support. Considering Gilat's operations on a per-region basis, the firm had six different entry modes in both the United States and the European Union, four different entry modes in South and Central America and two different entry modes in South East Asia.

The brief example of Gilat demonstrates the major weakness of extant literature on entry mode choice. Since value chain activities differ substantially in their scale and scope economics, resource requirements, asset specificity and strategic importance (Porter, 1985) firms may have different entry modes for different value chain activities and hence multiple entry modes per host market. Moreover, even when the same value chain activity is considered institutional and cultural differences between countries (Delios \& Henisz, 2003) are expected to lead to diversity in the inter-country entry modes chosen for a given value chain activity. It is highly unlikely that the managerial decisions on such entry modes are independent (take for instance the decision of which value chain activities to outsource and which to conduct inhouse, Quinn \& Hilmer, 1994) and thus the usefulness of analyzing a specific entry mode at the firm-country level, without referring to that firm's overall configuration of entry mode is quite limited (Buckley \& Hashai, 2004, 2005; Hill, Hwang \& Kim, 1990; Petersen, Benito, Welch, \& Asmussen, 2007). It is therefore questionable whether extant entry mode research has dealt with the full complexity of firms' 
foreign market entry mode choices and whether the economic factors shaping such choices have been fully unraveled.

The aim of this paper is to expand foreign market entry mode research by switching the unit of analysis from country specific entry mode to the analysis of multiple, rather than alternative, entry modes of a firm across its value chain and across foreign markets. By adopting this point of view, we are able to examine and compare the portfolios of entry modes used by different firms and determine the factors that affect the level of diversity of entry modes across the value chain and across host markets. We offer tentative answers to the question of why some firms use complex combinations of diverse entry modes while others follow a standardized approach applying only one or a few modes. More specifically, the paper explores the factors that shape the levels of diversity in firms' entry modes by examining the impact of two distinctive variables - scale of operations and knowledge intensity - on entry mode diversity.

The structure of the paper is as follows. In the next section we review different strands of literature and justify the need for considering scale of operations and knowledge intensity as potentially important determinants of firms' entry mode diversity. We then conceptualize entry mode diversity according to different levels of analysis (area level, business activity level, and corporate level) and derive hypotheses as to how scale of operations and knowledge intensity affect entry mode diversity at these three levels. The hypotheses derived from our conceptual framework are tested on data of entry modes used by a sample of Israeli based firms. This is followed by an analysis of the results and finally we discus our results, suggest further research avenues and conclude. 


\section{Determinants of Entry Mode Diversity - A Literature Review}

Extant literature on foreign market entry modes has its offspring in foreign direct investment (FDI) theory which explains the existence and growth of multinational enterprises (Buckley \& Casson, 1976; Hennart, 1982; Rugman, 1981, Teece, 1986a). Based on internalization and transaction cost economics explanations, this stream of literature was primarily focusing on the impact of failures in the market for firm specific know-how (most often referring to technological know-how) on firms' choice between licensing and wholly owned production subsidiaries. Over time, several intermediate arrangements such as equity and non-equity based alliances came to the forefront (Contractor \& Lorange, 1988; Hennart, 1988a, 1988b, 1991) and comprehensive models to predict the choice between licensing arrangements and production subsidiaries, between joint ventures and wholly-owned subsidiaries, or between exports and foreign production were developed (e.g. Anderson \& Gatignon, 1986; Dunning, 2001; Hennart, 1988a, 1988b; Hill, et al., 1990; Hirsch, 1976; Teece, 1986a). Drawing on market imperfection explanations, the political and economic institutional characteristics of foreign locations (Brouthers, 2002; Delios \& Henisz, 2003), the resource-based view of the firm (Anand \& Delios, 1997; Madhok, 1997) and the knowledge-based view of the firm (Kogut \& Zander, 1993; Martin \& Salomon, 2003), our understanding and predictive ability of entry modes decisions was significantly enriched.

Nevertheless, most of the aforementioned studies considered the firm as a "black box" and were (either explicitly or implicitly) motivated in explaining the existence or non-existence of international production (Dunning, 2001). Even when value chain activities other than production were introduced, a comprehensive view of multiple entry modes across the value chain or across different host markets was 
rarely taken. Marketing scholars interested in marketing channels integration have contrasted sales subsidiaries with local distributors and franchised outlets with company-owned ones (e.g. Anderson \& Coughlan, 1987; Fladmoe-Lindquist \& Jacque, 1995; Klein, Frazier \& Roth, 1990). Supply chain management scholars have contrasted in-house logistics with local, independent suppliers (Levy, 1997) and so forth. Scholars have typically not, however, looked at the value chain to its full extent in terms of the organization of entry modes.

In fact, market failure is not limited to the market for know-how but may relate to the markets for manufacturing, distribution, services, and to other markets. Likewise, resource- and knowledge-based explanations of entry modes as well as institutional arguments may naturally affect the whole value chain of internationalizing firms and may do so differently in various host markets. Furthermore, even within a given foreign market, firms often do not stick to one particular entry mode, but instead simultaneously employ a variety of entry modes at the value chain activity level (Benito \& Welch, 1994; Fina \& Rugman, 1996; Petersen \& Welch, 2002). We should therefore refer to a firm's entry mode decision not as a general decision at the firm-country level but rather as a per country and per value activity specific decision (Buckley \& Casson, 1998; Buckley \& Hashai, 2004, 2005; Casson, 2000). Our earlier example of Gilat Satellite Networks demonstrates both of these points of view nicely as Gilat simultaneously combine different entry modes across and within value chain activities as well as across and within host markets. Taken together, it is therefore implied that firms may often pursue a "portfolio" or "configuration" of entry modes constituting a much more complex structural arrangement of entry modes than that reflected by extant foreign market entry mode research. 
Foreign market entry mode scholars have given a particular emphasis to the examination of the need for control over foreign value chain activities, usually measured as the degree of equity ownership in a foreign operation. This line of research basically emerged as studies of FDI examined make-or-buy choices in an international setting. The dependent variables have thus either been: (a) dichotomous, i.e. make-or-buy choices, such as wholly-owned subsidiary versus licensing, (b) multiple ordinal categories, e.g. wholly-owned subsidiary versus partly-owned subsidiary (equity joint venture) versus licensing, or (c) some measure of the focal actor's degree of ownership in a foreign venture (Gatignon \& Anderson, 1988; Zhao, Luo \& Suh, 2004). Yet again, all these measures ignore potentially different control requirements corresponding to different value chain activities located in multiple host countries.

Gauging the diversity of a firm's entry mode configuration highlights the managerial complexity of handling different entry modes at a given foreign market as well as different entry modes across such markets. Since firms are often considered to be heterogeneous (Wernerfelt, 1984; Barney, 1991) it is reasonable to expect firms to differ in terms of entry mode diversity. Hence, it follows that compelling explanations of what accounts for inter-firm differences in entry mode diversity should be offered.

Among other variables, scale of operations and knowledge intensity are traditionally emphasized as two distinctive variables affecting foreign market entry mode choice (Anand \& Delios, 1997; Benito, 1996; Buckley \& Pearce, 1979; Datta et al., 2002; Delios \& Henisz, 2003; Gatignon \& Anderson, 1988; Kogut \& Singh, 1988; Tan et al., 2001). Scale of operations plays an important role in a firm's decision whether to export, license or open a foreign production facility (Agarwal \& Ramaswami, 1992; Aliber, 1970; Buckley \& Casson, 1981; Buckley \& Pearce, 1979). 
This is mainly due to the relationship between the scale of a firm's operations and relative fixed and variable costs. Ownership based operation modes typically require up-front investment, which implies high fixed costs, combined with low variable costs. By contrast, externalization appears to be associated with a combination of high variable and low fixed costs. Thus, other things being equal, cost minimization considerations are expected to lead smaller firms (e.g. in terms of their sales volume) to favor externalization and larger firms to favour a higher degree of ownership of value chain activities.

Knowledge intensity is often conceived as the single most important determinant of a firm's foreign operation mode (e.g. Buckley \& Casson, 1976; Buckley \& Hashai, 2004, 2005; Kim \& Hwang, 1992; Kumar, 1987; Martin \& Salomon, 2003). Knowledge intensity is reflected by the share of proprietary firm specific knowledge contained in each unit of output. The firm-specific nature of knowledge implies that higher levels of knowledge intensity are expected to be associated with higher complexity in the interpretation and transfer of such knowledge (Scuricini, 1988). The more complex a firm's knowledge base, the more costly is knowledge transfer both between value chain activities (Kogut \& Zander, 1992, 1993; Martin \& Salomon, 2003) and between the firm and its customers (Hirsch, 1989; Simonin, 1999) due to the fact that complex knowledge is often expected to be less codifiable and less teachable (Kogut \& Zander, 1993). Since organizational bonds are expected to significantly reduce the cost of such knowledge transfer (Kogut \& Zander, 1992, 1993; Martin \& Salomon, 2003) it follows that higher knowledge intensity is expected to be associated with greater degree of ownership. 
The level of knowledge intensity is also concomitant with high uncertainty which increases market transaction costs as the costs of monitoring, enforcing and regulating inter-firm contractual arrangements increase. These transaction costs imply that knowledge-intensive firms usually prefer internalization of their operations (Contractor, 1990; Kim \& Hwang, 1992; Osborn \& Baughn, 1990; Williamson, 1975). On the other hand, high knowledge intensity impels incumbents to source knowledge outside their firm boundaries as it becomes extremely difficult for the individual firm to maintain competitiveness for all its value chain activities when performed as in-house business activities (Teece, 1986b; Quinn \& Hilmer, 1994).

As scale of operations and knowledge intensity thus influence the entry mode decision, it is likely that the diversity of the firm's entry mode portfolio across countries and value activities is affected by these two variables as well. Therefore, building on the constructs of operational scale and knowledge intensity we next seek to explain how the diversity of firms' entry mode configurations is determined. However, before doing so we formally define the concept of entry mode diversity and its resulting aggregation levels.

\section{Conceptualizing Entry Mode Diversity}

The entry mode diversity of a given firm can be conceptualized and operationalized by looking at a matrix of the entry modes used by that firm (Petersen et al., 2007). Assume that an international firm operates in $I$ host markets and has $J$ identifiable activities in its value chain. Formally, the entry mode matrix of this firm at a given point in time is then defined as the matrix $\mathbf{M}=\left(m_{i j}\right)$, where $i=1 \ldots I$ indexes host markets and $j=1 \ldots J$ indexes value chain activities. Each cell in the matrix indicates under which entry mode (denoted as $m_{i j}$ ) the given activity is performed in 
the given host market. The general form of the entry mode matrix is presented in Figure 1.

\section{[Insert Figure 1 about here]}

The entry mode matrix implies that there are three levels of aggregation in which we can discuss entry mode diversity ${ }^{2}$ :

- Area level diversity refers to different entry modes exerted by a firm across its value chain in a given foreign area - country or region - and therefore can be represented as a row vector $m_{i \bullet} \equiv\left(m_{i 1}, m_{i 1}, \ldots, m_{i J}\right)$ of value activity-level decisions. For example, with six different entry modes, Gilat has high area diversity both in the United States and in the European Union.

- Business activity level diversity is about how a specific value chain activity is performed in different geographical areas (countries or regions), as measured by each column in the matrix. Business activity diversity for a given activity is therefore represented by a column vector of the form $m_{\bullet j} \equiv\left(m_{1 j}, m_{2 j}, \ldots, m_{I j}\right)$. With five different entry modes Gilat has high business activity diversity in distribution and customer support across countries and regions.

- Corporate level diversity represents the variety of entry modes in each cell of the entire matrix M. Designing this matrix encompasses all area-level and business activity level decisions.

The entry mode diversity matrix is reminiscent of Porter's (1986) global activity configuration grid. However, where Porter's grid refers only to the location of value chain activities, this matrix goes one step further to include the entry mode chosen for

\footnotetext{
${ }^{2}$ It is noteworthy that more than a single entry mode may apply to a specific value chain activity in a host market, hence duplicable value chain activity can be included as the matrix columns.
} 
each value chain activity as well. The main contribution of the matrix is that it explicitly incorporates a value chain distinction over multiple host countries and regions into traditional foreign entry mode taxonomies, resulting in a broader unit of analysis than that taken in extant entry mode literature (Datta et al., 2002).

\section{Entry mode diversity and scale of operation}

We take a cost-benefit approach to predict the entry mode diversity used by firms. Entry mode diversity can potentially affect both the firm's costs, conceptualized as the sum of its production and transaction costs (Williamson, 1975, 1985), and its revenue-enhancing assets. Our theoretical framework therefore incorporates these effects. The benefits of high diversity are derived per value chain activity and per host market heterogeneity in terms of economies of specialization. With high entry mode diversity, firms can optimize the operation of each individual value chain activity in each host market, obtaining a better overall fit with a heterogeneous set of specific foreign market conditions and/or activity-specific considerations. An important feature of these benefits is that they are contingent upon the scale of operations (e.g. sales volume, see Stigler, 1958; Williamson, 1967). For instance, if indigenous partners in a foreign market can provide certain components at a cost which is $x \%$ below the internal unit costs of a focal firm, selective outsourcing of the relevant manufacturing processes will save that firm $x \times V / 100$, where $V$ is the activity volume in this market. In a similar vein, if a potential R\&D or marketing partner with some specific competencies (such as reputation or special familiarity with customer preferences) enables the firm to charge a $x \%$ premium over its price, partnering will add $x \times V / 100$ to the firm's revenue. In both cases, the higher the sales, the higher the absolute contribution of a specific foreign market entry mode chosen. 
Moreover, indivisibility of assets and activities such as people, equipment or land (Penrose, 1959) makes a small scale firm more limited in its ability to split up its value chain into diversified entry modes. Take the extreme case of a one-man firm. Such a firm would naturally find it difficult to separate the economics of each value chain activity and outsource those that are least efficiently done in-house. A large firm, on the other hand, has more degrees of freedom to do so. Insufficient scale economies and asset indivisibility are expected to constrain small sized firms in their ability to differentiate their foreign operations in different host markets and either concentrate such activities in a limited number of locations (e.g. hold a single production plant worldwide) or combine various host markets under a limited number of entry modes (e.g. use the same agent for distribution in different regions). Hence, we suggest that the larger a firm, the higher the marginal benefits of entry mode diversity.

The costs of diversity are mainly the costs of searching for potential acquirees, partners, or suppliers of each value chain activity in each host market, soliciting offers, measuring and forecasting performance, and writing contracts (Buckley \& Casson, 1976; Hart, 1988, 1995; Williamson, 1975, 1985). Even in cases where all necessary information is easily obtained the interdependencies between value chain activities (Buckley \& Hashai, 2004, 2005) would make it difficult to configure and manage the entire value chain optimally. The number of options that a given firm's management has to choose between, and hence the cognitive costs incurred by the firm, rises exponentially with the number of value chain activities and host markets ${ }^{3}$. This implies that the more diverse the different entry mode configurations the more complex it is to manage them. Learning economies should decrease the costs of

\footnotetext{
${ }^{3}$ Even under the conservative assumption of a single entry mode per value chain activity, for $j$ value chain activities, $i$ host markets and $k$ potential entry modes for each activity, there are $k^{i \times j}$ potential corporate level entry mode configurations.
} 
managing low entry mode diversity since mangers can leverage their experience in managing a specific entry mode over multiple value chain activities and/or host markets. On the other hand, coordination costs as well as the transfer of knowledge between different partners engaged in different governance modes as well as between multiple intra-firm governance modes (e.g. greenfield and acquired operations) are expected to sharply rise with entry mode diversity. The main point is that both the transaction costs involved in engaging in multiple entry modes and the costs arising from the complexity of managing multiple highly diverse entry mode configurations are, by and large, fixed costs which do not increase linearly with activity volume to the same extent as the benefits from diversity do. In other words, there are economies of scale in search, contracting, coordination and deliberation processes.

Taken together, this suggests that the benefits of diversity are positively related to activity volume whereas the costs of diversity are not. These costs increase with the number of value chain activities considered, the number of host markets and the number of per value chain activity entry modes, rather than with the scale of operations. Figure 2 shows the marginal benefits (MB) for a low-volume and a highvolume firm, and their common marginal cost schedule (MC)

[Insert Figure 2 about here]

All else being equal, large firms enjoy higher marginal benefits and hence their optimal levels of diversity, $D_{1}$ (where the MB curve intercepts the MC curve), are larger than those of small firms $\left(D_{0}\right)$. This suggests that observed diversity should be positively related to activity volume. We therefore hypothesize that:

Hypothesis 1: Scale of operations positively affects entry mode diversity.

\section{Knowledge intensity and entry mode diversity}


Another central firm characteristic that affects the costs of entry mode diversity is knowledge intensity. As noted earlier the cost of knowledge flows between and within value chain activities (Buckley \& Hashai, 2004; Kogut \& Zander, 1993; Martin \& Salomon, 2003) are expected to be substantially higher for firms with high knowledge intensity than for firms with low knowledge intensity as higher knowledge intensity often implies higher complexity of coding and decoding the transferred knowledge. Higher diversity implies that such knowledge flows are conducted between different entry modes pursued by a focal firm. Higher diversity is therefore likely to result in greater costs of transferring complex knowledge, since it requires tight coordination of knowledge transfer between multiple partners engaging in different contractual arrangements as well as between those and multiple intra-firm entry modes.

Coupled with the transaction costs that are implied from the high uncertainty of running a highly knowledge intensive firm (Contractor, 1990; Kim \& Hwang, 1990; Osborn \& Baughn, 1990; Williamson, 1975) this means that more transaction and deliberation costs must be incurred for firms with high knowledge intensity than for firms with low knowledge intensity when engaging in high entry mode diversity. This is illustrated in Figure 3, where high knowledge intensity increases the marginal costs of diversity. Seen in isolation this increase would lead to a decrease in the optimal level of diversity, from $D_{0}$ to $D_{1}$.

\section{[Insert Figure 3 About Here]}

On the other hand, the benefits of diversity may also be affected by knowledge intensity. When value chain activities are subject to increasing complexity and require more and more human capital input the likelihood that these activities can be performed competitively within the boundaries of the individual firm is diminishing (Teece, 1986b; Quinn \& Hilmer, 1994). In other words, the conduct of sophisticated 
value chain activities compels knowledge-intensive firms to source multiple other firms' specific knowledge and combine it with internally developed capabilities.. Hence, specialized, highly knowledge-intensive firms are required to engage in a heterogeneous portfolio of agreements to obtain various complementary assets. Engaging in multiple agreements with multiple partners translates into entry mode diversity rather than into relying on a narrow set of entry modes. Such an interpretation is consistent with the relational-view of the firms (Dyer \& Singh, 1998; Kale, Dyer \& Singh, 2002; Lavie, 2006) that essentially implies that combining complementary capabilities of different firms may lead to sustainable competitive advantage.

In other words, at low levels of knowledge intensity firms are more likely to build on a relatively small number of entry modes per host market and per value chain activity, however as knowledge intensity increases, the level of sophistication required at each market and for each activity increases. At the value chain activity level increased entry mode diversity might be the result of the fact that at high knowledge intensity there are more diverse and more complex tasks to perform while at the host market level increased entry mode diversity mat result from heterogeneity in firms competences that require entrants to use multiple modes with different partners for R\&D, production, distribution and servicing.

More generally, the firm's choice of entry modes constitutes its organizational interface with different host country environments and thereby also determines which host country resources it can access. It follows from this that a diverse set of entry modes would allow for sourcing from a diverse pool of knowledge and resources, which may be particularly beneficial for knowledge-intensive firms. This suggests that the benefits of diversity, including sourcing of complementary resources through 
a heterogeneous set of organizational arrangements, are higher for knowledge intensive firms than for other firms. This is illustrated via the shifting marginal benefit curve in Figure 4 which, all else being equal, results in a higher optimal level of diversity at $D_{1}^{\prime}$ than in $D_{0}^{\prime}$.

\section{[Insert Figure 4 About Here]}

Taken together, the cost and benefit arguments illustrate that the relationship between knowledge intensity and diversity could potentially be either positive or negative, depending on how sensitive the costs and benefits of diversity are to knowledge intensity. A priori there is no reason to believe that one effect should be stronger or weaker than the other and it is thus ultimately an empirical question. Therefore we suggest the following competing hypotheses:

Hypothesis 2a: Knowledge intensity negatively affects entry mode diversity.

Hypothesis $2 \boldsymbol{b}$ : Knowledge intensity positively affects entry mode diversity.

\section{Data and methods}

Our hypotheses were tested on data obtained from Israel's largest publicly traded industrial firms. The original list included Israel's one hundred and fifty largest industrial firms, which exported at least $25 \%$ of their sales. Combined exports by these 150 firms represented about 80 percent of Israel's industrial exports in 1999. The list was based on data received from Israel’s Ministry of Industry and Trade and data provided by Dun \& Bradstreet (2000). After eliminating foreign affiliates, conglomerates and firms which were not publicly traded we were left with a sample of 101 firms. To obtain a balanced panel we further eliminated all firms with missing data for any variable for either of the years of 1995 and 1999. Hence, the final sample 
consisted of 67 firms that provided useable information, including questionnaire data ${ }^{4}$. Comparisons between the 67 participating firms and the 34 non-participating firms did not show evidence of any response bias in terms of firm sales, number of employees, age, industrial classification and percentage of foreign sales.

For the purpose of the current study we have obtained the following information from the questionnaires. First, we needed to construct measures for entry mode diversity. Each firm in the sample has reported its foreign market entry modes in the years 1995 and 1999 for four major value chain activities (R\&D, production, distribution and customer support) and for six major regions (United States, European Union, Rest of America, Rest of Europe, South East Asia and Rest of the World). Since data collection of per country and per value chain activity entry modes is extremely complex we decided to focus on region-specific entry modes at the value chain activity level. This approach is quite common in extant literature (e.g. Almor et al, 2006; Kim et al, 1993; Rugman \& Verbeke, 2004; Yeung, Poon \& Perry, 2001) and reflects the tendency of firms to configure their operations at a regional, rather than a country level. Such an approach is especially feasible for small and mediumsized firms which are resource constrained. As shown later, this firm size characteristic fits our sample well.

For each value chain activity and each region one or more of the following entry modes could be assigned:

1. Export by means of an agent/ distributor

2. Export by means of a wholly owned sales office in country of destination

3. Strategic alliance with a local company

4. Original Equipment Manufacturer (OEM)

\footnotetext{
${ }^{4}$ Data was obtained from the financial statements of the firms and through structured interviews with CEO and VP level executives.
} 
5. International joint venture

6. A wholly owned greenfield subsidiary

7. A wholly owned acquired subsidiary

\section{Dependent variables}

Following the aggregation levels of diversity suggested in the conceptual framework section we defined three measures of entry mode diversity, which were calculated for each of the years 1995 and 1999. Area diversity describes the variation in entry modes across business activities (value chain activities) within a given location. For each area (region) $i$, we measured the number of entry modes used throughout the value chain. These area-level numbers were then averaged to arrive at the firm's overall area diversity. Business activity diversity describes a firm's tendency to vary its entry modes of a specific value chain activity across locations (regions). For each value chain activity $j$, we measured the number of entry modes used worldwide. The two variables - area and business activity diversity - capture variations along the two dimensions of the entry mode diversity matrix (cf. Figure 1). For example, a firm which always uses joint ventures for production and always wholly-owned subsidiaries for R\&D would have a higher degree of area diversity than of business activity diversity as it does not adapt its governance form to individual locations. Conversely, a firm using wholly-owned subsidiaries for all activities in Europe and joint ventures for all activities in Asia would have a higher degree of business activity diversity than of area diversity as it does not distinguish between different value chain activities in its governance forms. Finally, corporate diversity is the number of different entry modes found in the entire entry mode diversity matrix of the firm. This captures variations along both the area and business activity dimensions. 


\section{Independent Variables}

Our independent variables included were: (1) Scale of operations - measured as firm size in terms of total revenues (in US\$) in a given year; and (2) Knowledge intensity - measured as the ratio of $\mathrm{R} \& \mathrm{D}$ outlays to sales in a given year. As both variables were heavily skewed to the left, we performed logarithmic transformations on them, bringing skewness values down from above 3 to within \pm 0.5 . In order to alleviate multicollinearity problems when including the interaction term, the two variables were also centered so as to have a mean of zero.

In addition we used several control variables. Firm year of establishment was used to control for the impact of accumulated managerial experience on entry mode diversity. Industry dummies were also used to control for industry specific effects (such as: per industry regulation, industry specific transaction costs, industrial organization) on entry mode choice and hence on entry mode diversity. Since our sample did not include conglomerates, we could classify the firms in our sample into the following industries: (1) chemicals; (2) food \& beverage; (3) metal; (4) rubber, plastic, wood \& paper; (5) textile \& clothing; (6) electronics and computer hardware; (7) software; (8) telecommunication; (9) pharmaceuticals and (10) other. After controlling for other effects five of these industries were identified as having relatively more diversified entry modes than other industries: Rubber and plastic, textile and clothing, electronics and computer hardware, telecommunications and metal. Industry dummies for these five industries were therefore used as control variables. Furthermore, we controlled for the scope of foreign operations, defined as the number of cells (region-business activity combinations) in the entry mode matrix occupied by the firm. All else being equal, firms with operations in many locations, performing many value chain activities, can have higher diversity between those 
operations than can firms with only a limited scope of international activity. Finally, as a robustness check, we included the interaction term of knowledge intensity and size in our model. This enables us to check whether the impact of firm size is valid for all levels of knowledge intensity, and vice versa.

Table 1 depicts the descriptive statistics and correlations of our sample. The mean establishment year of the firms in the sample was 1975. The average sales revenue was 128,012 (\$ US thousands), and R\&D expenditures constituted 12\% of revenue. This implies that the firms in our sample are typically small- to mediumsized and that many of them can be considered as knowledge-intensive. These firms have a relatively higher level of business activity diversity than of area diversity. There are high correlations between the three measures of diversity, while no specific correlations were identified between the independent variables except between firm size and scope of foreign operations.

[Insert Table 1 about here]

We used panel data models to analyze our sample. Panel data models allow estimation of cross-sectional (firm) effects, time effects, or both. Initially we estimated all three types of models to evaluate the importance of each of these two dimensions. The two-way models with both time and firm effects were almost identical to the one-way cross-sectional models, and the time effect was insignificant for all dependent variables except corporate diversity, where it was only significant at the $p=0.05$ level. Therefore, we concluded that incorporating time-varying intercepts or errors would not justify the resulting decline in parsimony and degrees of freedom, and we proceeded to estimate a series of one-way models with only firm-specific effects. 
For each of the three dependent variables we developed three models: a pooled OLS regression, a fixed effects model allowing for firm-specific intercepts, and a random effects model treating the error term as firm-specific. Each of these models is reported both with and without the control variables, i.e. scope of foreign operations, industry, and firm year of establishment. Note that the traditional fixed effects estimator does not allow time-invariant control variables (industry and firm year of establishment) since these are perfectly collinear with the firm dummies. Hence, to include these variables in the fixed effects model, we used the unit effect vector decomposition technique developed by Plumper and Troeger (2004). In this approach the estimated firm-specific intercepts are regressed on the time-invariant variables and the residual from this regression is used as a predictor in a pooled OLS regression along with the time-varying and time-invariant variables. This effectively decomposes the firm-specific fixed effect into two orthogonal components: one which is explained by the time-invariant variables - in our case, an industry-specific and age-related component - and a residual component of firm effects not explained by these variables (and hence caused by other, unobserved variables). While it produces the same R square, the technique is more efficient than the fixed effect model, especially if the time-varying independent variables are "almost time-invariant" and if the sample is small (as in our case). It has also been shown in Monte Carlo simulations to outperform the pooled OLS, random effects, and Hausman-Taylor instrumental variables approaches in terms of consistency and unbiasedness (Plumper and Troeger, 2004).

\section{Results}


The results of our panel data models regressions are presented in Tables 2-4. For each model we present the regression results with and without the control variables.

[Insert Tables 2-4 about here]

For all dependent variables, adding the fixed firm-specific effects to the pooled OLS regression increases the variance explained from about $20 \%$ to more than $80 \%$. The F-test confirms that these group effects are significant, which implies that the pooled OLS regression without group effects may be biased. The pooled OLS regression is also rejected by the significance of the $L M$ statistic, which in all cases favors the random effects model (Breusch and Pagan, 1979).

For all three diversity measures, the Hausman $m$-value is insignificant, implying that the estimates produced by the fixed and random effects models are similar and that the random effects model is not biased (Hausman, 1978). A casual comparison of the coefficients confirms this. The somewhat lower significance for the fixed effects coefficients can be attributed to the lower efficiency of this model and the large share of variance captured by the firm dummies, which reflects the general advantage of using a random effects specification in small samples. Alternatively, the vector decomposition model (model 4 in all three tables) is similar to the fixed effects model but more efficient. The results of all the diversity models are generally robust to different model specifications. Variance inflation factors are reported for model 4, and as they are all quite low (much lower than the recommended threshold of 10), multicollinearity can be assumed not to significantly bias the results (Neter, Wasserman \& Kutner, 1990). 
Overall, the results of all the models presented in Tables 2-4 indicate that there is a positive correlation between scale (measured by firm size) and entry mode diversity thus confirming hypothesis 1 . The results also indicate that knowledge intensity is positively related to entry mode diversity. Hence, hypothesis 2a is rejected in favour of a positive relationship between knowledge intensity and diversity as predicted by our competing hypothesis $2 \mathrm{~b}$. As for the control variables, firm age (the opposite of year of establishment which is used as the independent variable) is negatively correlated to spatial entry mode diversity. The industry effects were found to be different in the three models, and the scope of foreign operations was positively related to diversity. The interaction of scale of operations and knowledge intensity did not have a significant effect on any of the three diversity types analyzed, confirming that the two variables are independent and not interactive determinants of foreign entry mode diversity.

\section{Discussion}

Our analysis of area level, business activity level and corporate level entry mode diversity reveals several interesting findings. First, we were able to support the hypotheses that there are economies of scale in entry mode diversity, resulting in relatively higher benefits (cost savings or value creation) than costs as scale increases. This result was consistent across all our diversity measures and indicates that larger firms benefit more than small ones from having diverse entry modes across host markets and value chain activities.

A more interesting finding, however, is the positive relationship found between knowledge intensity and entry mode diversity. The finding that firms of high knowledge intensity pursue more diverse entry modes is by no means a trivial one in a theoretical perspective as a cost-benefit argument provided indications for both a 
positive and a negative effect of knowledge intensity on entry mode diversity. Consequently, we developed competing sets of hypotheses. Our results indicate that the need for complementary assets and capabilities residing with several firms overrule transaction cost and knowledge transfer cost effects. Hence, firms operating in knowledge-intensive industries combine multiple agreements with other firms and internally developed capabilities - despite the transaction costs involved in such a diverse set of organizational arrangements.

The high correlations among our dependent variables indicate that the three diversity types are strongly related, and the empirical analysis shows that they are more or less determined by the same organizational characteristics. As a scale, the three items have Cronbach's Alpha of 0.89 and they all load on the same factor in a post-hoc confirmatory factor analysis. This could indicate that entry mode diversity is indeed a firm-level construct. On the other hand, our data also reveals slight but interesting differences between the different dimensions of diversity. For example, high diversity can be expected to occur more frequently within specific locations (countries and regions) than within specific business activities across locations. This finding indicates that cross-national/regional differences (culture, language, laws and regulations etc.) have a considerable impact on choice of entry mode, and thereby on entry mode diversity. Also, the finding that age is negatively correlated with entry mode diversity on area level indicates that younger firms have more diversified entry modes within particular locations. This may imply that in their early years in a certain foreign market, firms experiment with all sorts of entry modes, but that after a period of trial and error a relatively narrower set of the most efficient entry modes is chosen within that specific location. Interestingly, such an entry mode diversity effect is absent at the business activity level and corporate diversity level, implying that across 
areas entry mode diversity is maintained regardless of age. This may reflect the perseverance of country differences and the increase in local embeddedness over time, making it difficult for firms to standardize their entry modes across borders once these are well established.

There are several avenues for future research on entry mode diversity. First of all, more research is required in order to analyze the impact of additional factors on entry mode diversity. Moreover, while scale of operations and knowledge intensity were found to be significant in explaining entry mode diversity, it might still be that after a certain threshold of scale and knowledge intensity transaction costs reduce the benefits of increased diversity. Thus, similar studies relating to larger firms and to firms with a more diverse range of knowledge intensity may help us to strengthen the external validity of the linkage between operational scale, knowledge intensity and entry mode diversity. Exploring the dynamics in entry mode diversity (Petersen \& Welch, 2002) is yet another potentially important line of research, as understanding how and why firms configure and re-configure their entry modes should garner further insights on the process of entry mode selection.

In addition, a plausible avenue for future research will be to explore the relationship between entry mode ownership level and entry mode diversity. When looking at the various entry modes chosen for different value chain activities in different host countries we may not only calculate various diversity measures but also refer to an "average” degree of ownership. Entry mode configuration ownership can be thought of as the "mean" degree of ownership or internalization across a given firm's value chain, where entry mode diversity can be thought of as the "variance" of such ownership degrees. Both the ownership and diversity of entry mode configurations are potentially important factors as they enhance our conceptualization 
of foreign market entry modes from an ordinal categorical variable to a continuous variable which may be characterized by its mean and variance. Finally, there is much room to investigate the performance implications of entry mode diversity. Unravelling the relationship between entry mode diversity and performance is of utmost importance for better understanding the linkage between entry modes and performance.

\section{Conclusion}

This paper advances the vast literature on entry mode by introducing the concepts of entry mode diversity. By changing the unit of analysis from a single entry mode to multiple entry modes on geographical area level, business activity level, and corporate level we are able to enrich entry mode research design and investigate in more detail the parameters that affect the choice of certain levels of ownership and diversity. More specifically, when studying the factors affecting entry mode diversity we have two central findings: (1) We found that there are economies of scale leading to higher diversity levels for large firms; (2) We have identified a positive relationship between knowledge intensity and entry mode diversity, presumably indicating that highly knowledge intensive firms specialize in specific areas of expertise leading them to pursue multiple entry modes with multiple partners.

These findings suggest that managers should consider their entry mode decisions by taking an overall view of their specific value chain activities and their worldwide dispersion rather than taking such decisions in isolation for each entry mode. Moreover, the design of an optimal entry mode configuration at the area, business activity and corporate level should be done by taking into account the effects of operations scale and knowledge intensity. 


\section{References}

Aliber, R.Z. (1970). A theory of direct foreign investment. In Kindleberger, C.P. (ed.), The International Firm. Cambridge, MA: MIT press.

Almor, T., Hashai, N. and Hirsch, S. (2006), The product cycle revisited - knowledge intensity and firm internationalization, Management International Review, 46(5), p.655-675.

Anand, J. and Delios, A. (1997). Location specificity and the transferability of downstream assets to foreign subsidiaries. Journal of International Business Studies, 28, 579- 603 .

Anderson, E. and Gatignon, H.A. (1986). Modes of foreign entry: a transaction cost analysis and propositions. Journal of International Business Studies, 17(3), 1-26.

Anderson, E. and Coughlan, A.T. (1987). International market entry and expansion via independent or integrated channels of distribution. Journal of Marketing, 51(1), 71-82.

Barney, J.B. (1991). Firm resources and sustained competitive advantage. Journal of Management, 17, 99-120

Benito, G.R.G. (1996). Ownership structures of Norwegian foreign subsidiaries in manufacturing. International Trade Journal, 10(2), 157-198.

Benito, G.R.G. and Welch, L.S. (1994). Foreign market servicing: beyond choice of entry mode. Journal of International Marketing, 2(2), 7-27.

Breusch, T. and Pagan, A. (1979). A simple test of heteroskedasticity and random coefficient variation. Econometrica, 47, 1287-1294.

Brouthers, K.D. (2002). Institutional culture and transaction cost influences on entry mode choice and performance. Journal of International Business Studies, 33 (2), 203221.

Buckley, P.J. and Casson, M. (1976). The Future of the Multinational Enterprise. London: Macmillan

Buckley, P.J. and Casson, M. (1981). The optimal timing of a foreign direct investment. Economic Journal, 91, 75-87.

Buckley, P.J. and Casson, M. (1998). Analysing foreign market entry strategies: extending the internalisation approach. Journal of International Business Studies, 29(3), 539-561.

Buckley, P.J. and Hashai, N. (2004). A global system view of firm boundaries. Journal of International Business Studies, 35, 33-45. 
Buckley, P.J. and Hashai, N. (2005). Firm configuration and internationalisation: a model. International Business Review, 14(6), 655-675.

Buckley, P.J. and Pearce, R.D. (1979). Overseas production and exporting by the world's largest enterprises: a study in sourcing policy. Journal of International Business Studies, 10(1), 9-20.

Casson, M. (2000). The Economics of International Business - A New Research Agenda. Cheltenham, UK: Edward Elgar.

Contractor, F.J. (1990). Contractual and cooperative forms of international business: towards a unified theory of modal choice. Management International Review, 30(1), 31-54.

Contractor, F.J. and Lorange P., 1988. Why should firms cooperate? The strategy and economics basis for cooperative ventures. In Contractor F.J. and Lorange P. (eds.), Cooperative Strategies in International Business. Massachusetts/Toronto: Lexington Books.

Datta, D. K., Herrmann, P. and Rasheed, A. A. (2002). Choice of foreign market entry modes: critical review and future directions. Advances in International Management, 14: 85-153.

Delios, A. and Henisz W. J. (2003). Political hazards, experience, and sequential entry strategies: the international expansion of Japanese firms, 1980-1998. Strategic Management Journal, 24(11), 1153-1164.

Dun \& Bradstreet (2000), DunsGuide Israel 2000, Tel Aviv: Dun \& Bradstreet.

Dunning, J.H. (2001). The key literature on IB activities: 1960-2000. In A. M. Rugman and A. Verbeke (eds.), The Oxford Handbook of International Business. Oxford: Oxford University Press.

Dyer, J. H. and Singh, H. (1998). The relational view: cooperative strategy and sources of interorganizational competitive advantage. The Academy of Management Review, 23(4), 660-679.

Fina, E. and Rugman, A. M. (1996). A test of internationalization theory: the Upjohn Company. Management International Review, 36(3), 199-213.

Fladmoe-Lindquist, K. and Jacque, L. L. (1995). Control modes in international service operations: the propensity to franchise. Management Science, 41(7), 12381249.

Gatignon, H. and Anderson, E. (1988). The multinational corporation's degree of control over foreign subsidiaries: an empirical test of a transaction cost explanation. Journal of Law, Economics and Organization, 4(2), 305-36.

Hart, O. (1988). Incomplete contracts and the theory of the firm. Journal of Law, Economics and Organization, 4, 119-139. 
Hart, O. (1995). Firms, Contracts, and Financial Structure. Oxford, UK: Oxford University Press.

Hausman, J. (1978). Specification test in econometrics. Econometrica, 46, 1251-1272.

Hennart, J.-F. (1982). A Theory of Multinational Enterprise. Ann Arbor, MI: The University of Michigan Press.

Hennart, J.-F. (1988a). A transaction cost theory of equity joint ventures. Strategic Management Journal, 9(4), 361-374.

Hennart, J.-F. (1988b). Upstream vertical integration in the world aluminum and tin industries: a comparative study of the choice between market and intrafirm coordination. Journal of Economic Behavior and Organization, 9(3), 281-300.

Hennart, J.-F. (1991). The transaction cost theory of the multinational enterprise. In Pitelis and Sugden (eds.) The Nature of the Transnational Firm. London: Routledge.

Hill, C.W.L., Hwang, P. and Kim, W. C. (1990). An eclectic theory of the choice of international entry mode. Strategic Management Journal, 11, 117-128.

Hirsch, S. (1976). An international trade and investment theory of the firm. Oxford Economic Papers, 28, 258- 270.

Hirsch, S. (1989). Services and service intensity in international trade. Weltwirtschaffliches Archiv - Review of World Economics, 125(1), 45-60.

Kale, P., Dyer, J. H. and Singh, H. (2002). Alliance capability, stock market response, and long term alliance success: the role of the alliance function. Strategic Management Journal, 23 (8), 747-767.

Kim, W.C. and Hwang, P. (1992). Global strategy and multinationals' entry mode choice. Journal of International Business Studies, 23(1), 29-53.

Klein S., Frazier, G.L., Roth, V.J. (1990). A transaction cost analysis model of channel integration in international markets. Journal of Marketing Research, 27, 196208.

Kogut, B. and Singh H. (1988). The effect of national culture on the choice of entry mode. Journal of International Business Studies, 19, 411-432.

Kogut, B. and Zander, U. (1992). Knowledge of the firm, combinative capabilities and the replication of technology. Organization Science 3(3), 383-397.

Kogut, B. and Zander, U. (1993). Knowledge of the firm and the evolutionary theory of the multinational corporation. Journal of International Business Studies, 24(4), 625-645.

Lavie, D. (2006). Capability reconfiguration: an analysis of incumbent responses to 
technological change. Academy of Management Review, 31, 153-174.

Levy, D.L. (1997). Lean production in an international supply chain. Sloan Management Review, 38(2), 94-102.

Madhok, A. (1997). Cost, value and foreign market entry mode: the transaction and the firm. Strategic Management Journal, 18(1), 39-61.

Malhotra, N.K., Agarwal, J. and Ulgado, F.M. (2003). Internationalization and entry modes: a multitheoretical framework and research propositions. Journal of International Marketing, 11(4), 1-31.

Martin, X. and Salomon, R. (2003). Knowledge transfer capacity and its implications for the theory of the multinational corporation. Journal of International Business Studies, 34(4), 356-373.

Melin, L. (1992). Internationalization as a strategy process. Strategic Management Journal, 13, 99-118

Neter, J., Wasserman, W., and Kutner, M. H. (1985). Applied Linear Statistical Models: Regression, Analysis of Variance, and Experimental Design. Homewood, Illinois: Richard D. Irwin, Inc.

Osborn, R.N. and Baughn, C.C. (1990). Forms of interorganizational governance for multinational alliances. The Academy of Management Journal, 33(3), 503-519.

Pedersen, T., Petersen, B. and Benito, G.R.G. (2002). Foreign operation method change: impetus and switching costs. International Business Review, 11(3), 325-345.

Penrose, E. T. (1959), The Theory of the Growth of the Firm. John Wiley: New York.

Petersen, B. and Welch, L.S. (2002). Foreign operation mode combination and internationalization. International Business Review, 55(2). 157-162.

Petersen, B., Benito, G.R.G., Welch, L.S. and Asmussen, C.G. (2007). Mode configuration diversity: a new perspective on foreign operation mode choice. In D. Griffith (ed.), Emerging Research Frontiers in International Business Studies, Volume 2. London: Palgrave.

Plumper, T. and Troeger, V.E. (2004). The estimation of time-invariant variables in panel analyses with unit fixed effects. Social Science Research Network, Working Paper.

Porter, M.E. (1985). Competitive Advantage. New York: Free Press.

Porter, M.E. (1986). Competition in global industries: a conceptual framework. In M.E. Porter (ed.), Competition in Global Industries. Cambridge, MA: Harvard Business School Press. 
Quinn, J.B. and Hilmer, F.G. (1994). Strategic outsourcing. Sloan Management Review, 35 (4), 43-55.

Rugman, A.M. (1981). Inside the Multinationals: The Economics of Internal Markets. Columbia University Press: New York.

Rugman, AM, and Verbeke, A. (2004). A perspective on regional and global strategies of multinational enterprises. Journal of International Business Studies, 35(1), 3-18.

Scuricini, G.B. (1988). Complexity in large technological systems. In Peliti, L. and Vulpiaini, A. (eds.), Measures of Complexity. New York: Springer Verlag.

Simonin, B.L., (1999). Transfer of marketing know-how in international strategic alliances: an empirical investigation of the role and antecedents of knowledge ambiguity. Journal of International Business Studies, 30, 463-490.

Stigler, G.J. (1958). The economies of scale. Journal of Law and Economics, 1, 5471.

Tan, B., Erramilli, K. and Liang, T.W. (2001). The influence of dissemination risks, strategic control and global management skills on firms' modal decision in host countries. International Business Review, 10(3), 323-340.

Teece, D.J. (1986a). Transaction cost economics and the multinational enterprise: an assessment. Journal of Economic Behavior and Organization, 7, 21-45.

Teece, D.J. (1986b). Profiting from technological innovation: implications for integration, collaboration, licensing and public policy. Research Policy, 15, 785-805.

Wernerfelt, B. (1984). A resource-based view of the firm. Strategic Management Journal, 5(2), 171-181.

Williamson, O.E. (1967). Hierarchical control and optimum firm size. Journal of Political Economy, 75 (2),123-138.

Williamson, O.E. (1975). Markets and Hierarchies: Analysis and Anti-Trust Applications. New York: The Free Press.

Williamson, O.E. (1985). The Economic Institutions of Capitalism. New York: The Free Press.

Yeung, H.W., Poon, J. and Perry, M. (2001). Towards a regional strategy: the role of regional headquarters of foreign firms in Singapore. Urban Studies, 38(1), 157-183.

Zhao, H., Luo, Y. and Suh, T. (2004). Transaction cost determinants and ownershipbased entry mode choice: a meta-analytical review. Journal of International Business Studies, 35(6), 524-545. 
Figure 1 - Entry mode diversity matrix

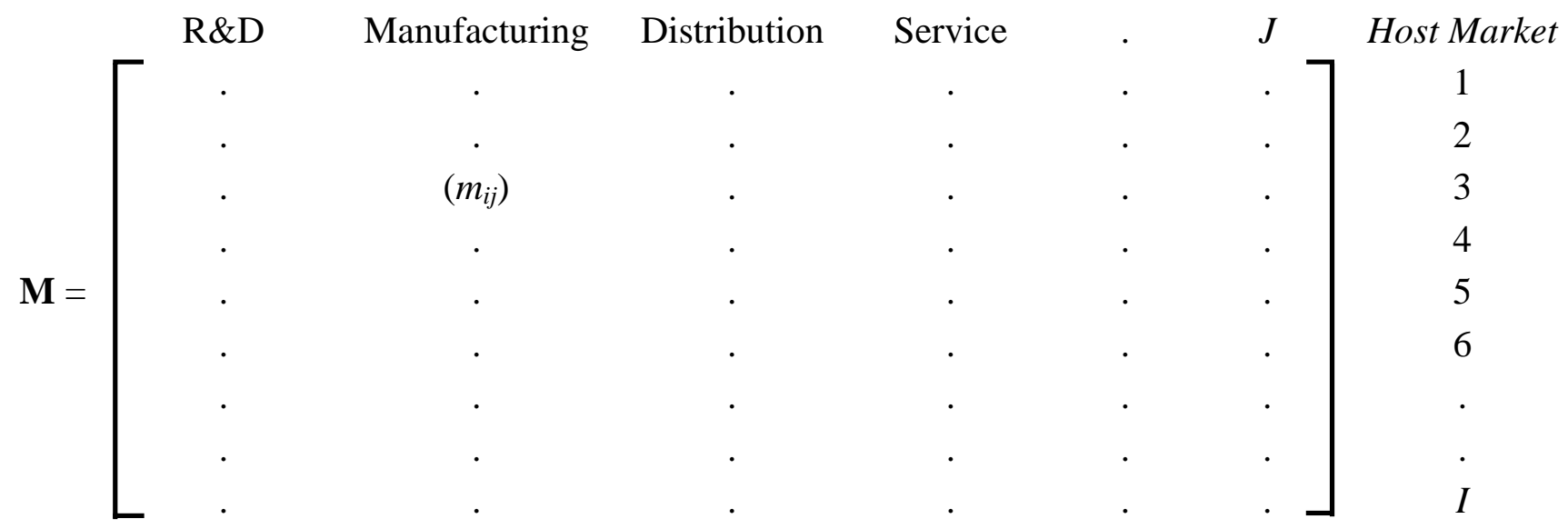

Source: Adapted from Petersen et al. (2007)

Figure 2 - Scale of operations and marginal costs and benefits of entry mode diversity

Marginal costs/benefits

of diversity

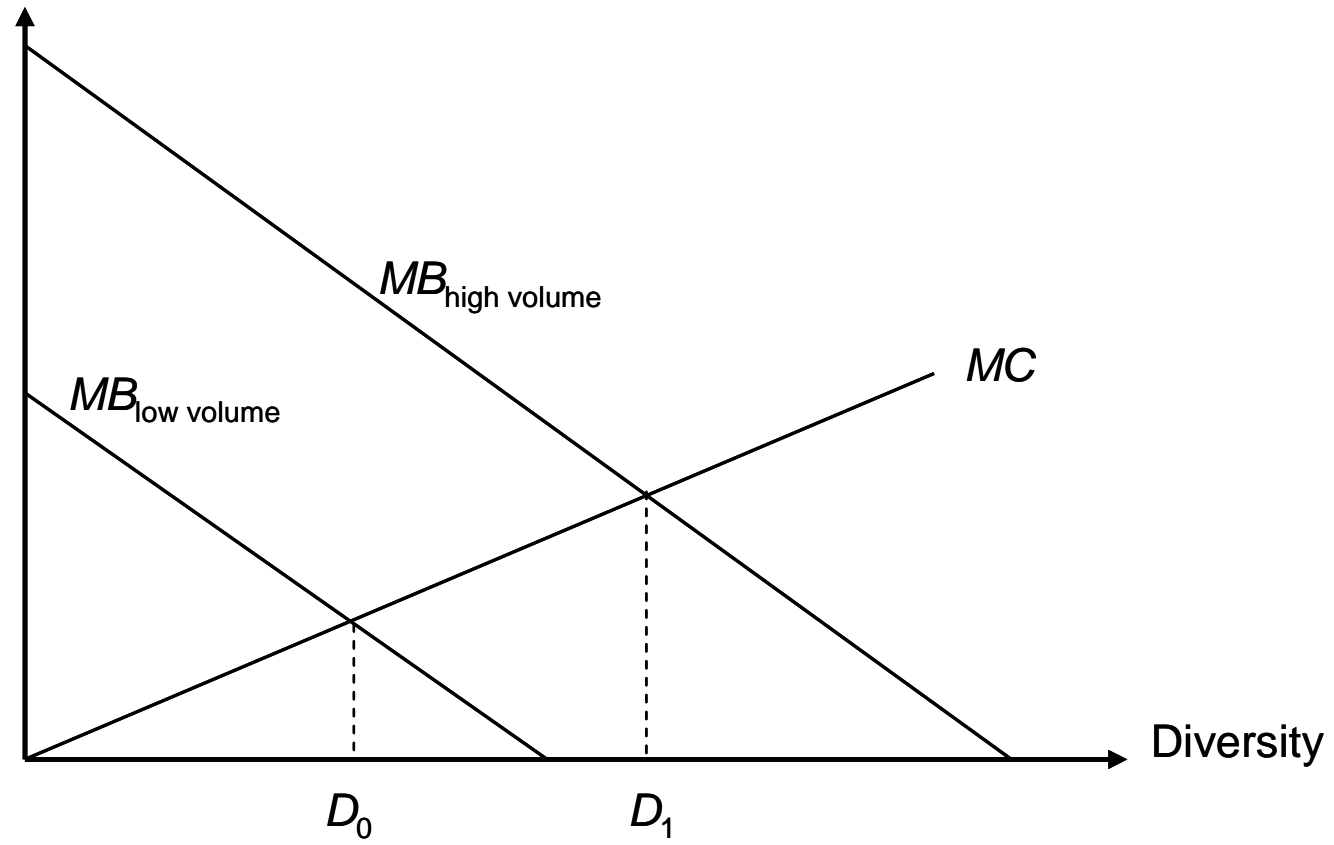


Figure 3 - Knowledge intensity and marginal costs of entry mode diversity

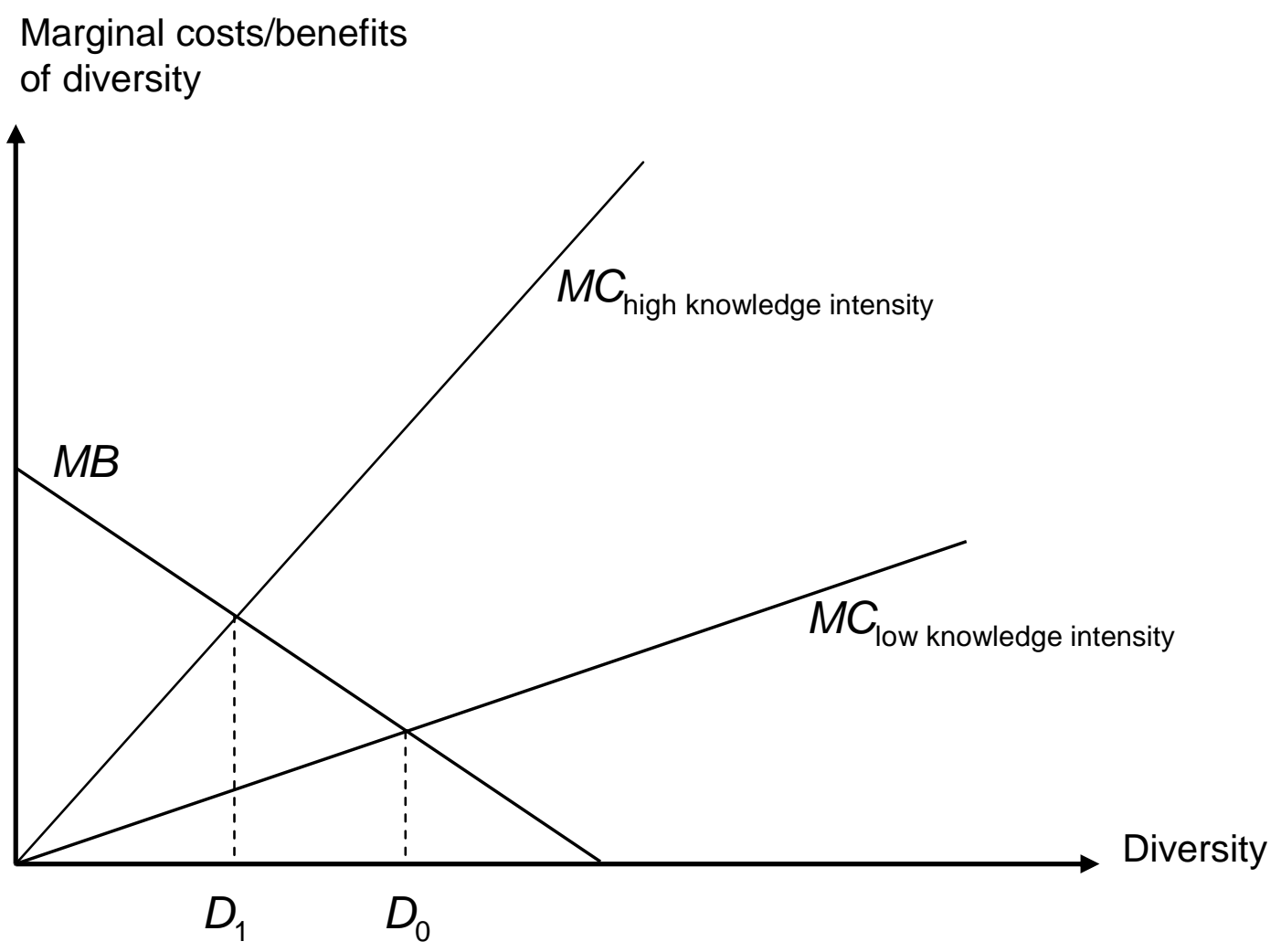

Figure 4 - Knowledge intensity and marginal benefits of entry mode diversity

Marginal costs/benefits of diversity

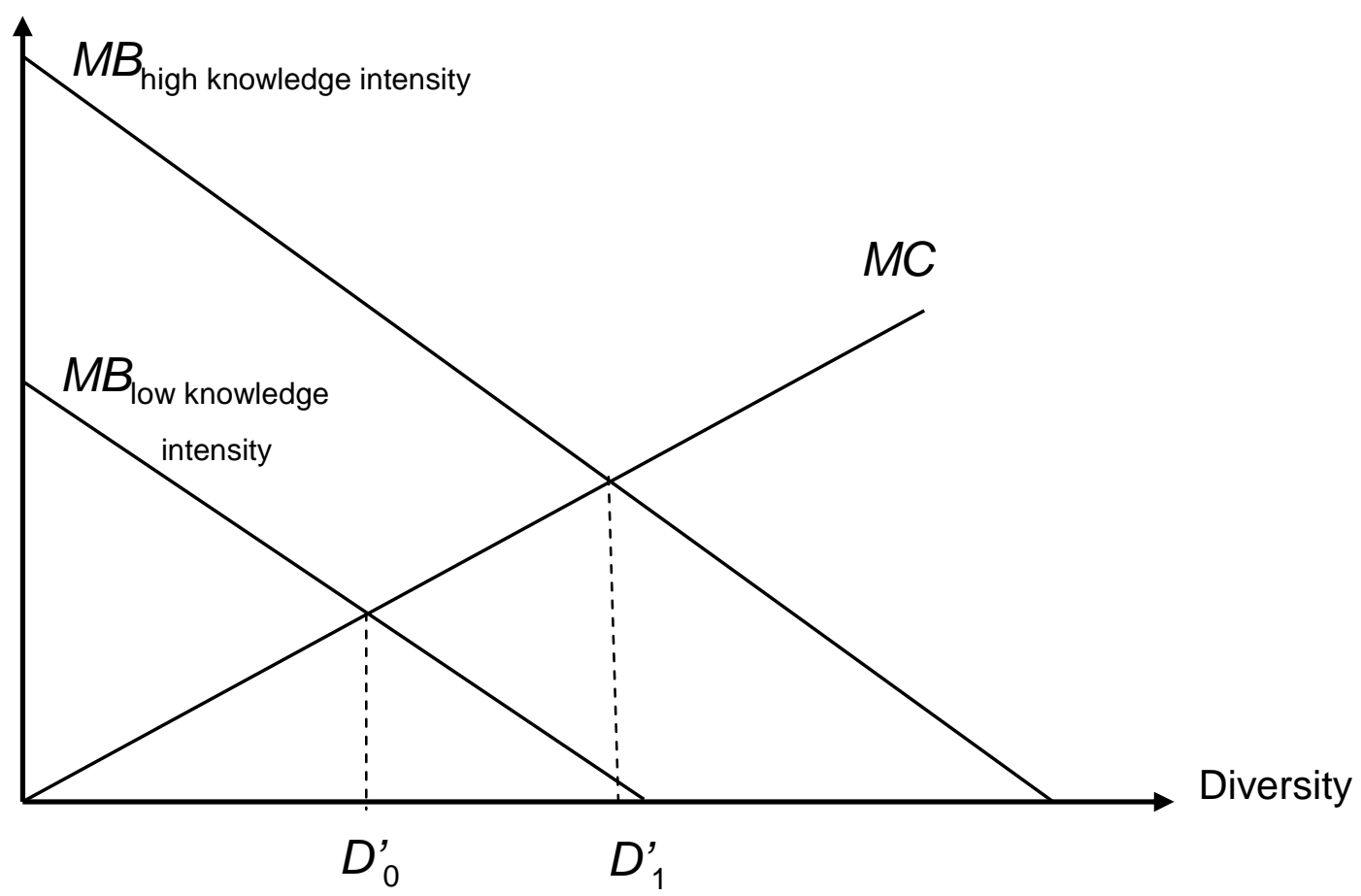


$\underline{\text { Table } 1 \text { - Descriptive statistics and correlations }(\mathrm{N}=67)}$

\begin{tabular}{llllllll}
\hline Variable & Mean & St. Dev. & $\mathbf{1}$ & $\mathbf{2}$ & $\mathbf{3}$ & $\mathbf{4}$ & $\mathbf{5}$ \\
\hline 1. Area Diversity & 1.72 & 0.80 & - & & & & \\
2. Business Activity Diversity & 1.99 & 0.84 & $0.66^{* *}$ & - & & & \\
3. Corporate Diversity & 2.49 & 1.32 & $0.84^{* *}$ & $0.83^{* *}$ & - & & \\
4. R\&D Intensity & 0.12 & 0.20 & $0.21^{*}$ & $0.22^{*}$ & $0.22^{*}$ & - & \\
5. Sales (\$ US thousands) & 128,012 & 200,338 & 0.00 & 0.15 & 0.15 & -0.17 & - \\
6. Scope of Foreign Operations & 5.91 & 3.58 & $0.42^{* *}$ & $0.41^{* *}$ & $0.56^{* *}$ & 0.14 & $0.34^{* *}$ \\
\hline
\end{tabular}

* Significant at $\mathrm{p}=0.05$

** Significant at $\mathrm{p}=0.01$

$\underline{\text { Table } 2}$ - Panel data regression analysis (dependent variable $=$ Area diversity)

\begin{tabular}{|c|c|c|c|c|c|c|c|}
\hline $\begin{array}{l}\text { Dependent } \\
\text { variable: } \\
\text { Area } \\
\text { Diversity } \\
\quad \text { Model }\end{array}$ & Pooled C & LS & $\begin{array}{l}\text { Fixed E } \\
\text { (OLS) }\end{array}$ & ects & $\begin{array}{l}\text { Random } \\
\text { (GLS) }\end{array}$ & Effects & VIF \\
\hline $\begin{array}{l}\text { Knowledge } \\
\text { Intensity }\end{array}$ & $1.15^{* *}$ & $0.88 * *$ & $1.42 * *$ & $1.21 * *$ & $1.23^{* *}$ & $1.02 * *$ & 2.17 \\
\hline $\begin{array}{l}\text { Size } \\
\text { Knowledge } \\
\text { Intensity } \times \text { Size }\end{array}$ & $\begin{array}{l}0.22 * * \\
0.04\end{array}$ & $\begin{array}{l}0.22 * * \\
-0.07\end{array}$ & $\begin{array}{l}0.37 * * \\
-0.24\end{array}$ & $\begin{array}{l}0.26^{* *} \\
-0.17\end{array}$ & $\begin{array}{l}0.27 * * \\
-0.05\end{array}$ & $\begin{array}{l}0.24^{* *} \\
-0.11\end{array}$ & $\begin{array}{l}2.20 \\
1.30\end{array}$ \\
\hline $\begin{array}{l}\text { Scope of } \\
\text { Foreign } \\
\text { Operations }\end{array}$ & & $0.05 *$ & & $0.08 * *$ & & $0.06 *$ & 1.86 \\
\hline $\begin{array}{l}\text { Establishment } \\
\text { Year }\end{array}$ & & $0.01 *$ & & $0.01 * *$ & & 0.01 & 1.51 \\
\hline Metal & & 0.55 & & $0.87 * *$ & & 0.67 & 1.29 \\
\hline Rubber/Plastic & & -0.07 & & 0.18 & & 0.03 & 1.36 \\
\hline Textiles & & 0.37 & & $0.67 * *$ & & 0.49 & 1.50 \\
\hline Electronics & & 0.16 & & $0.23^{*}$ & & 0.19 & 1.30 \\
\hline Telecom & & 0.01 & & 0.00 & & 0.01 & 1.26 \\
\hline $\begin{array}{l}R^{2} \\
F\end{array}$ & $\begin{array}{l}0.22 \\
11.93 * *\end{array}$ & $\begin{array}{l}0.31 \\
5.52 * *\end{array}$ & $\begin{array}{l}0.86 \\
4.60 * *\end{array}$ & $\begin{array}{l}0.87 \\
51.13^{* *}\end{array}$ & 0.25 & 0.33 & \\
\hline $\begin{array}{l}\text { Hausman } m \\
\text { Breusch- } \\
\text { Pagan } L M\end{array}$ & & & & & $\begin{array}{l}3.12 \\
26.60 * *\end{array}$ & $-\overline{25.54 * *}$ & \\
\hline $\mathrm{N}$ & 134 & 134 & 67 & 67 & 67 & 67 & \\
\hline \multicolumn{8}{|c|}{$\begin{array}{l}\text { Intercept, firm dummies (model 3), and residual firm-specific effects (model } 4 \text { ) suppressed. } \\
\text { F-test reported for model } 3 \text { is a test of fixed effects, i.e. joint significance of the firm dummies. F-test } \\
\text { for model } 4 \text { is test of entire model including independent variables and firm dummies. } \\
\text { Time-invariant control variables explain } 16 \% \text { of firm-specific effect (model } 4 \text { ). } \\
\text { Model } 4 t \text {-values deflated by } 66 \text { degrees of freedom to compensate for the three-stage approach. } \\
\text { * Significant at } p=0.05 \\
* * \text { Significant at } p=0.01\end{array}$} \\
\hline
\end{tabular}


Table 3 - Panel data regression analysis (dependent variable $=$ Business activity diversity)

\begin{tabular}{|c|c|c|c|c|c|c|c|}
\hline $\begin{array}{l}\text { Dependent } \\
\text { variable: } \\
\text { Business } \\
\text { Activity } \\
\text { Diversity } \\
\quad \text { Model }\end{array}$ & \multicolumn{2}{|c|}{ Pooled OLS } & $\begin{array}{l}\text { Fixed E } \\
\text { (OLS) }\end{array}$ & ects & $\begin{array}{l}\text { Random } \\
\text { (GLS) }\end{array}$ & Effects & $\begin{array}{r}\text { VIF } \\
\\
4 \\
\end{array}$ \\
\hline $\begin{array}{l}\text { Knowledge } \\
\text { Intensity }\end{array}$ & $1.20 * *$ & $0.62 *$ & $1.33 * *$ & $1.19 * *$ & $1.26^{* *}$ & $1.02 * *$ & 2.24 \\
\hline $\begin{array}{l}\text { Size } \\
\text { Knowledge } \\
\text { Intensity } \times \text { Size }\end{array}$ & $\begin{array}{l}0.11^{*} \\
0.01\end{array}$ & $\begin{array}{l}0.09 \\
-0.12\end{array}$ & $\begin{array}{l}0.23^{*} \\
0.06\end{array}$ & $\begin{array}{l}0.16^{* *} \\
0.11\end{array}$ & $\begin{array}{l}0.15^{*} \\
0.06\end{array}$ & $\begin{array}{l}0.24 * * \\
-0.11\end{array}$ & $\begin{array}{l}2.22 \\
1.33\end{array}$ \\
\hline $\begin{array}{l}\text { Scope of } \\
\text { Foreign } \\
\text { Operations }\end{array}$ & & $0.08 * *$ & & $0.05 * *$ & & $0.06 *$ & 1.87 \\
\hline $\begin{array}{l}\text { Establishment } \\
\text { Year }\end{array}$ & & 0.01 & & 0.01 & & 0.01 & 1.51 \\
\hline Metal & & 0.47 & & $0.56^{*}$ & & 0.67 & 1.28 \\
\hline Rubber/Plastic & & -0.06 & & -0.01 & & 0.03 & 1.34 \\
\hline Textiles & & 0.32 & & 0.37 & & 0.49 & 1.48 \\
\hline Electronics & & $0.56^{* *}$ & & $0.47 * *$ & & 0.19 & 1.30 \\
\hline Telecom & & 0.44 & & $0.46^{*}$ & & 0.01 & 1.26 \\
\hline$R^{2}$ & 0.18 & 0.35 & 0.82 & 0.82 & 0.17 & 0.33 & \\
\hline $\begin{array}{l}F \\
\text { Hausman } m \\
\text { Breusch- } \\
\text { Pagan } L M\end{array}$ & $9.54 * *$ & $6.56^{* *}$ & $3.47 * *$ & $34.95^{* *}$ & $\begin{array}{l}2.23 \\
19.86 * *\end{array}$ & - $25.54 * *$ & \\
\hline $\mathrm{N}$ & 134 & 134 & 67 & 67 & 67 & 67 & \\
\hline $\begin{array}{l}\text { Intercept, firm dum } \\
\text { F-test reported for } ~ \\
\text { for model } 4 \text { is test } \\
\text { Time-invariant con } \\
\text { Model } 4 t \text {-values d } \\
\text { * Significant at } p=0 \\
* * \text { Significant at } p=\end{array}$ & $\begin{array}{l}\text { mies (mod } \\
\text { model } 3 \text { is } \\
\text { of entire mc } \\
\text { trol variabl } \\
\text { eflated by } 6 \\
0.05 \\
=0.01\end{array}$ & $\begin{array}{l}\text { 3), and re } \\
\text { test of fixe } \\
\text { lel includil } \\
\text { s explain } 1 \\
\text { degrees o }\end{array}$ & $\begin{array}{l}\text { dual firm- } \\
\text { effects, i. } \\
\text { independ } \\
\text { \% of firm- } \\
\text { reedom tc }\end{array}$ & $\begin{array}{l}\text { cific effects } \\
\text { oint signific } \\
\text { variables a } \\
\text { cific effect } \\
\text { mpensate f }\end{array}$ & $\begin{array}{l}\text { (model 4) } \\
\text { ince of the f } \\
\text { d firm dum } \\
\text { (model 4). } \\
\text { in the three- }\end{array}$ & $\begin{array}{l}\text { ppressed. } \\
\text { m dummie } \\
\text { lies. } \\
\text { age approa }\end{array}$ & -test \\
\hline
\end{tabular}


$\underline{\text { Table } 4 \text { - Panel data regression analysis (dependent variable }=\text { Corporate diversity) }}$

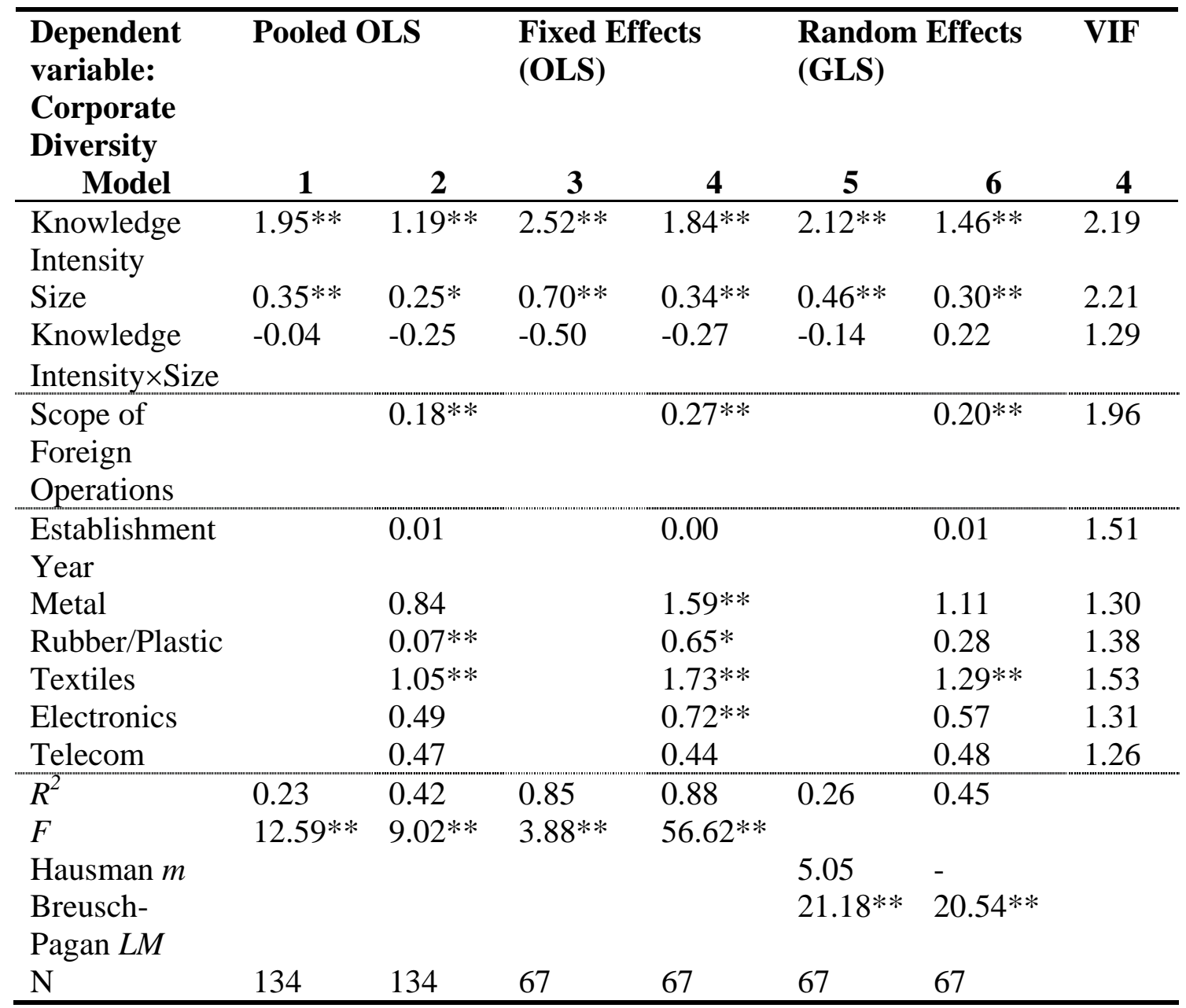

Intercept, firm dummies (model 3), and residual firm-specific effects (model 4) suppressed.

F-test reported for model 3 is a test of fixed effects, i.e. joint significance of the firm dummies. F-test

for model 4 is test of entire model including independent variables and firm dummies.

Time-invariant control variables explain $26 \%$ of firm-specific effect (model 4).

Model $4 t$-values deflated by 66 degrees of freedom to compensate for the three-stage approach.

* Significant at $\mathrm{p}=0.05$

** Significant at $\mathrm{p}=0.01$ 


\section{SMG - Working Papers \\ www.cbs.dk/smg \\ 2003}

2003-1: Nicolai J. Foss, Kenneth Husted, Snejina Michailova, and Torben Pedersen: Governing Knowledge Processes: Theoretical Foundations and Research Opportunities.

2003-2: Yves Doz, Nicolai J. Foss, Stefanie Lenway, Marjorie Lyles, Silvia Massini, Thomas P. Murtha and Torben Pedersen: Future Frontiers in International Management Research: Innovation, Knowledge Creation, and Change in Multinational Companies.

2003-3: Snejina Michailova and Kate Hutchings: The Impact of In-Groups and OutGroups on Knowledge Sharing in Russia and China CKG Working Paper.

2003-4: Nicolai J. Foss and Torben Pedersen : The MNC as a Knowledge Structure: The Roles of Knowledge Sources and Organizational Instruments in MNC Knowledge Management CKG Working Paper.

2003-5: Kirsten Foss, Nicolai J. Foss and Xosé H. Vázquez-Vicente: “Tying the Manager's Hands": How Firms Can Make Credible Commitments That Make Opportunistic Managerial Intervention Less Likely CKG Working Paper.

2003-6: Marjorie Lyles, Torben Pedersen and Bent Petersen: Knowledge Gaps: The Case of Knowledge about Foreign Entry.

2003-7: Kirsten Foss and Nicolai J. Foss: The Limits to Designed Orders: Authority under "Distributed Knowledge" CKG Working Paper.

2003-8: Jens Gammelgaard and Torben Pedersen: Internal versus External Knowledge Sourcing of Subsidiaries - An Organizational Trade-Off.

2003-9: Kate Hutchings and Snejina Michailova: Facilitating Knowledge Sharing in Russian and Chinese Subsidiaries: The Importance of Groups and Personal Networks Accepted for publication in Journal of Knowledge Management.

2003-10: Volker Mahnke, Torben Pedersen and Markus Verzin: The Impact of Knowledge Management on MNC Subsidiary Performance: the Role of Absorptive Capacity CKG Working Paper.

2003-11: Tomas Hellström and Kenneth Husted: Mapping Knowledge and Intellectual Capital in Academic Environments: A Focus Group Study Accepted for publication in Journal of Intellectual Capital CKG Working Paper.

2003-12: Nicolai J Foss: Cognition and Motivation in the Theory of the Firm: Interaction or "Never the Twain Shall Meet"? Accepted for publication in Journal des Economistes et des Etudes Humaines CKG Working Paper.

2003-13: Dana Minbaeva and Snejina Michailova: Knowledge Transfer and Expatriation Practices in MNCs: The Role of Disseminative Capacity.

2003-14: Christian Vintergaard and Kenneth Husted: Enhancing Selective Capacity Through Venture Bases. 


\section{4}

2004-1: Nicolai J. Foss: Knowledge and Organization in the Theory of the Multinational Corporation: Some Foundational Issues

2004-2: Dana B. Minbaeva: HRM Practices and MNC Knowledge Transfer

2004-3: Bo Bernhard Nielsen and Snejina Michailova: Toward a Phase-Model of Global Knowledge Management Systems in Multinational Corporations

2004-4: Kirsten Foss \& Nicolai J Foss: The Next Step in the Evolution of the RBV: Integration with Transaction Cost Economics

2004-5: Teppo Felin \& Nicolai J. Foss: Methodological Individualism and the Organizational Capabilities Approach

2004-6: Jens Gammelgaard, Kenneth Husted, Snejina Michailova: Knowledge-sharing Behavior and Post-acquisition Integration Failure

2004-7: Jens Gammelgaard: Multinational Exploration of Acquired R\&D Activities

2004-8: Christoph Dörrenbächer \& Jens Gammelgaard: Subsidiary Upgrading? Strategic Inertia in the Development of German-owned Subsidiaries in Hungary

2004-9: Kirsten Foss \& Nicolai J. Foss: Resources and Transaction Costs: How the Economics of Property Rights Furthers the Resource-based View

2004-10: Jens Gammelgaard \& Thomas Ritter: The Knowledge Retrieval Matrix: Codification and Personification as Separate Strategies

2004-11: Nicolai J. Foss \& Peter G. Klein: Entrepreneurship and the Economic Theory of the Firm: Any Gains from Trade?

2004-12: Akshey Gupta \& Snejina Michailova: Knowledge Sharing in Knowledge-Intensive Firms: Opportunities and Limitations of Knowledge Codification

2004-13: Snejina Michailova \& Kate Hutchings: Knowledge Sharing and National Culture: A Comparison Between China and Russia

\section{5}

2005-1: Keld Laursen \& Ammon Salter: My Precious - The Role of Appropriability Strategies in Shaping Innovative Performance

2005-2: Nicolai J. Foss \& Peter G. Klein: The Theory of the Firm and Its Critics: A Stocktaking and Assessment

2005-3: Lars Bo Jeppesen \& Lars Frederiksen: Why Firm-Established User Communities Work for Innovation: The Personal Attributes of Innovative Users in the Case of Computer-Controlled Music

2005-4: Dana B. Minbaeva: Negative Impact of HRM Complementarity on Knowledge Transfer in MNCs

2005-5: Kirsten Foss, Nicolai J. Foss, Peter G. Klein \& Sandra K. Klein: Austrian Capital Theory and the Link Between Entrepreneurship and the Theory of the Firm 
2005-1: Nicolai J. Foss: The Knowledge Governance Approach

2005-2: Torben J. Andersen: Capital Structure, Environmental Dynamism, Innovation Strategy, and Strategic Risk Management

2005-3: Torben J. Andersen: A Strategic Risk Management Framework for Multinational Enterprise

2005-4: Peter Holdt Christensen: Facilitating Knowledge Sharing: A Conceptual Framework

2005-5 Kirsten Foss \& Nicolai J. Foss: Hands Off! How Organizational Design Can Make Delegation Credible

2005-6 Marjorie A. Lyles, Torben Pedersen \& Bent Petersen: Closing the Knowledge Gap in Foreign Markets - A Learning Perspective

2005-7 Christian Geisler Asmussen, Torben Pedersen \& Bent Petersen: How do we Capture "Global Specialization" when Measuring Firms' Degree of internationalization?

2005-8 Kirsten Foss \& Nicolai J. Foss: Simon on Problem-Solving: Implications for New Organizational Forms

2005-9 Birgitte Grøgaard, Carmine Gioia \& Gabriel R.G. Benito: An Empirical Investigation of the Role of Industry Factors in the Internationalization Patterns of Firms

2005-10 Torben J. Andersen: The Performance and Risk Management Implications of Multinationality: An Industry Perspective

2005-11 Nicolai J. Foss: The Scientific Progress in Strategic Management: The case of the Resource-based view

2005-12 Koen H. Heimeriks: Alliance Capability as a Mediator Between Experience and Alliance Performance: An Empirical Investigation Into the Alliance Capability Development Process

2005-13 Koen H. Heimeriks, Geert Duysters \& Wim Vanhaverbeke: Developing Alliance Capabilities: An Empirical Study

2005-14 JC Spender: Management, Rational or Creative? A Knowledge-Based Discussion

\section{6}

2006-1: Nicolai J. Foss \& Peter G. Klein: The Emergence of the Modern Theory of the Firm

2006-2: Teppo Felin \& Nicolai J. Foss: Individuals and Organizations: Thoughts on a Micro-Foundations Project for Strategic Management and Organizational Analysis

2006-3: Volker Mahnke, Torben Pedersen \& Markus Venzin: Does Knowledge Sharing Pay? An MNC Subsidiary Perspective on Knowledge Outflows

2006-4: Torben Pedersen: Determining Factors of Subsidiary Development 
2006-5 Ibuki Ishikawa: The Source of Competitive Advantage and Entrepreneurial Judgment in the RBV: Insights from the Austrian School Perspective

2006-6 Nicolai J. Foss \& Ibuki Ishikawa: Towards a Dynamic Resource-Based View: Insights from Austrian Capital and Entrepreneurship Theory

2006-7 Kirsten Foss \& Nicolai J. Foss: Entrepreneurship, Transaction Costs, and Resource Attributes

2006-8 Kirsten Foss, Nicolai J. Foss \& Peter G. Klein: Original and Derived Judgement: An Entrepreneurial Theory of Economic Organization

2006-9 Mia Reinholt: No More Polarization, Please! Towards a More Nuanced Perspective on Motivation in Organizations

2006-10 Angelika Lindstrand, Sara Melen \& Emilia Rovira: Turning social capital into business? A study of Swedish biotech firms' international expansion

2006-11 Christian Geisler Asmussen, Torben Pedersen \& Charles Dhanaraj: Evolution of Subsidiary Competences: Extending the Diamond Network Model

2006-12 John Holt, William R. Purcell, Sidney J. Gray \& Torben Pedersen: Decision Factors Influencing MNEs Regional Headquarters Location Selection Strategies

2006-13 Peter Maskell, Torben Pedersen, Bent Petersen \& Jens Dick-Nielsen: Learning Paths to Offshore Outsourcing - From Cost Reduction to Knowledge Seeking

2006-14 Christian Geisler Asmussen: Local, Regional or Global? Quantifying MNC Geographic Scope

2006-15 Christian Bjørnskov \& Nicolai J. Foss: Economic Freedom and Entrepreneurial Activity: Some Cross-Country Evidence

2006-16 Nicolai J. Foss \& Giampaolo Garzarelli: Institutions as Knowledge Capital: Ludwig M. Lachmann's Interpretative Institutionalism

2006-17 Koen H. Heimriks \& Jeffrey J. Reuer: How to Build Alliance Capabilities

2006-18 Nicolai J. Foss, Peter G. Klein, Yasemin Y. Kor \& Joseph T. Mahoney: Entrepreneurship, Subjectivism, and the Resource - Based View: Towards a New Synthesis

\section{7}

2007-1 Peter Abell, Teppo Felin \& Nicolai J. Foss: Building Micro-Foundations for the Routines, Capabilities, and Performance Links

2007-2 Michael W. Hansen, Torben Pedersen \& Bent Petersen: MNC Strategies and Linkage Effects in Developing Countries

2007-3 Niron Hashai, Christian G. Asmussen, Gabriel R.G. Benito \& Bent Petersen: Predicting the Diversity of Foreign Entry Modes 